\title{
Peripartum cardiomyopathy co-existing with severe preeclampsia complicated by AKI
}

\author{
Tonmoy Das, Alaka Goswami, Himleena Gautam, Maileng Tham, Anupama Hajong, \\ Nahid Farzin, Nilanjana Das
}

Correspondence: Dr. Himleena Gautam, Department of Obstetrics and Gynaecology, Apollo Hospitals, Guwahati; Email - himleenaj@gmail.com

Distributed under Attribution - NonCommercial - Share Alike 4.0 International (CC BY-NC-SA 4.0)

\begin{abstract}
Peripartum cardiomyopathy is a rare idiopathic cardiac disease occurring in pregnancy and puerperium. Studies have shown that women with preeclampsia have a higher risk of developing peripartum cardiomyopathy. In this report we present a case of a $3^{\text {rd }}$ trimester pregnancy with severe preeclampsia with acute kidney injury who was diagnosed with peripartum cardiomyopathy. Supportive management was done with a multidisciplinary approach. Caesarean section was done, an IUGR but healthy baby was delivered and the patient recovered gradually.
\end{abstract}

Keywords: Cardiomyopathy, pregnancy, idiopathic, preeclampsia, acute kidney injury, multidisciplinary.

Peripartum cardiomyopathy (PPCM) is a type of dilated cardiomyopathy presenting with heart failure secondary to left ventricular (LV) systolic dysfunction towards the end of pregnancy or in the puerperium period (usually within 5 months), where no other cause of heart failure is found (American Heart Association, European Society of Cardiology). Echocardiographic findings include ejection fraction (EF) of below $45 \%$ and/or fractional shortening of less than $30 \%$ or end-diastolic dimension of more than $2.7 \mathrm{~cm} / \mathrm{m} 2$ with or without $\mathrm{LV}$ dilatation. The overall incidence of PPCM is around 1 in $2000{ }^{1}$ with mortality of more than $50 \%$. Common risk factors for PPCM are advanced maternal age, gestational hypertension, preeclampsia, multiparity, multiple gestations, obesity, diabetes, substance and tobacco abuse and family history ${ }^{2}$. Complications include thromboembolism, arrhythmias and myocardial infarction.

Preeclampsia is a multiorgan disease, which is considered to be severe when BP is greater than 160/110 $\mathrm{mm} \mathrm{Hg}$, proteinuria is greater than $5 \mathrm{gm}$ or signs and symptoms are consistent with end organ damage such as headache, visual disturbances, impaired coagulation, impaired hepatic function, impaired renal function or pulmonary edema. It has been observed that PPCM is seen more in parturients with preeclampsia, incidence ranging $2-68 \%^{3,4}$, but the reason is not known.

Acute kidney injury (AKI) in pregnancy is a clinical challenge with significant morbidity and mortality. Studies suggest an overall incidence of AKI in

Received: $22^{\text {nd }}$ August 2018. Accepted: $2^{\text {nd }}$ April 2019.

Das T, Goswami A, Gautam H, Tham M, Hajong A, Farzin N, Das N. Peripartum cardiomyopathy co-existing with severe preeclampsia complicated by AKI. The New Indian Journal of OBGYN. 2019; 6(1): 63-6. 
preeclampsia is $1.5-2 \%{ }^{5}$ with maternal mortality rates of $0-10 \%$, and perinatal mortality rates of $34-41 \%$ and short-term dialysis rates of $10-50 \%$. Managing PPCM with severe preeclampsia is very challenging and needs combined effort of cardiologist, obstetrician, intensivist, anesthesiologist, and neonatologist.

\section{Case report}

A 34 year old nullipara with history of 1 spontaneous abortion was referred from a peripheral centre at 35 weeks with post IUI pregnancy with breathing difficulty for 1week and uncontrolled BP. She was diagnosed with PIH 3 weeks back and was on tablet amlodipine $5 \mathrm{mg}$. She has been on thyroxine $75 \mathrm{mcg}$ for last 10 years due to was 32weeks and FHR was regular and reactive. On chest auscultation occasional fine crepitations were present with $\mathrm{SpO}_{2}$ of $95 \%$. As advised by Cardiologist, she was started with nitroglycerine infusion, furosemide injection, ipratropium nebulisation along with tablet amlodipine. Loading dose of Inj. $\mathrm{MgSO}_{4}$ was given and Inj. Betnesol $12 \mathrm{gm}$ IM given for fetal lung maturity. $\mathrm{O}_{2}$ inhalation started and patient was kept in propped up position.

Investigations revealed that her creatinine was $3.11 \mathrm{mg} / \mathrm{dl}$ with hyperkalemia and elevated liver enzymes (Table I). Gastroenterology consultation was taken. Patient was then shifted to ICU due to uncontrolled BP and multiorgan involvement. Labetalol infusion was

Table 1: Investigations of the patient

\begin{tabular}{|c|c|c|c|c|c|c|c|c|}
\hline Days & $\begin{array}{l}\text { Serum } \\
\text { creatinine } \\
\text { mg/dl }\end{array}$ & $\begin{array}{l}\text { Blood } \\
\text { urea in } \\
\text { mg/dl }\end{array}$ & $\begin{array}{l}\text { Serum } \\
\mathrm{Na}+\text { in } \\
\mathrm{mmol} / \mathrm{L}\end{array}$ & $\begin{array}{l}\text { Serum } \\
\mathrm{K}+\text { in } \\
\mathrm{mmol} / \mathrm{L}\end{array}$ & $\begin{array}{l}\text { SGOT } \\
(\mathbf{U} / \mathbf{L})\end{array}$ & $\begin{array}{l}\text { SGPT } \\
(\mathrm{U} / \mathrm{L})\end{array}$ & $\begin{array}{l}\text { Hb in } \\
\mathrm{gm} / \mathrm{dl}\end{array}$ & Others \\
\hline Day 1 & 2.98 & 65 & 145 & 5.2 & 419 & 544 & 9.9 & $\begin{array}{l}\text { ALKP- 241U/L } \\
\text { PT-10.4 sec } \\
\text { Serum bilirubin - } \\
0.71 \mathrm{mg} / \mathrm{dl} \\
\text { Platelet - } 2.15 \mathrm{lacs} / \mathrm{mm} 3 \\
\text { Urine albumin- } 2+\end{array}$ \\
\hline Day 2 & 3.11 & & & 5.9 & 420 & 674 & & $\begin{array}{l}\text { USG - hepatomegaly, } \\
\text { bilateral raised renal } \\
\text { cortical echoes }\end{array}$ \\
\hline Day 3 & & & & 6.1 & 476 & 822 & & \\
\hline Day 4 & 3.45 & 106 & & 5.9 & 398 & 774 & 10.2 & Serum uric acid- $12 \mathrm{mg} / \mathrm{dl}$ \\
\hline Day 5 & 3.35 & 106 & 142 & 4.6 & 430 & 686 & & PT- $10.7 \mathrm{sec}$ \\
\hline \multicolumn{9}{|c|}{ From day 6 till onset of labour parameters were almost plateau } \\
\hline $\begin{array}{l}\text { On day of } \\
\text { operation }\end{array}$ & 3.74 & 127 & 141 & 5 & 260 & 567 & 8.8 & $\begin{array}{l}\text { Serum albumin- } 1.9 \mathrm{gm} / \mathrm{dl} \\
\text { BT,CT.PT were normal }\end{array}$ \\
\hline \multicolumn{9}{|c|}{$\begin{array}{l}\text { Patient had oliguria and acute LVF prior to operation and developed cardiogenic shock and acidosis after operation. } \\
\text { Hemodialysis was done }\end{array}$} \\
\hline $\begin{array}{l}\text { Post op } \\
\text { day } 2\end{array}$ & 4.04 & 131 & 141 & 6.7 & 574 & 578 & 8 & \\
\hline \multicolumn{9}{|c|}{ PPH occurred. Oxytocin infusion given. } \\
\hline $\begin{array}{l}\text { Post op } \\
\text { day } 3\end{array}$ & 5.83 & 162 & 149 & 4.9 & 293 & 414 & $\begin{array}{l}6.7(\mathrm{PRBC} \\
\& \text { FFP } \\
\text { given) }\end{array}$ & PT-11.2sec \\
\hline $\begin{array}{l}\text { Post op } \\
\text { day } 5\end{array}$ & 5.3 & 180 & 147 & 4.7 & 126 & 382 & 8 & \\
\hline \multicolumn{9}{|c|}{ Serum creatinine and liver enzymes were gradually declining. } \\
\hline $\begin{array}{l}\text { Before } \\
\text { discharge }\end{array}$ & 4.6 & 121 & 142 & 3.8 & 32 & 146 & & Urine albumin- trace \\
\hline $\begin{array}{l}\text { hypothyroi } \\
\text { pulse rate } \\
\text { of } 170 / 120\end{array}$ & $\begin{array}{l}\text { ism. On adn } \\
\text { f } 100 \mathrm{bpm}, \mathrm{r} \\
\text { amHg. On ol }\end{array}$ & $\begin{array}{l}\text { ission, e } \\
\text { spiratory }\end{array}$ & $\begin{array}{l}\text { ma was } p \\
\text { ate of } 18 / 1\end{array}$ & $\begin{array}{l}\text { nt, with } \\
\text { and BP } \\
\text { ll height }\end{array}$ & $\begin{array}{l}\text { starte } \\
\text { insuli } \\
\text { salbu }\end{array}$ & and $\mathrm{c}$ & $\begin{array}{l}\text { ection of } 1 \\
\text { infusion, ca } \\
\text { lisation. } \mathrm{H}\end{array}$ & $\begin{array}{l}\text { perkalemia was done with } \\
\text { ium gluconate injection and } \\
\text { respiratory difficulty was }\end{array}$ \\
\hline
\end{tabular}


relieved to some extent and on $3^{\text {rd }}$ admission day her BP was under control and antihypertensive infusions were stopped. Orally nifedipine and labetalol were continued. But her creatinine and liver enzymes were elevated further, with slight fall in potassium level. Echocardiography showed moderate LV systolic dysfunction, $\mathrm{EF}$ of around $35 \%$ with moderate to severe $\mathrm{MR}$, thus suggesting PPCM. Fluids were restricted to 1.5 litres/day. CPAP was started from $4^{\text {th }}$ day of admission. Creatinine levels were gradually declining.

During her stay fetal monitoring was done using frequent FHR auscultation and alternate day doppler study. On $10^{\text {th }}$ day of admission, she went into labour. She developed acute respiratory distress with anuria and was diagnosed with acute LVF. Emergency LSCS was done under general anaesthesia with cardiac monitoring. A $1.9 \mathrm{~kg}$ IUGR female baby was delivered. Patient was kept under mechanical ventilation postoperatively.

Patient went into cardiogenic shock after 2 hours of operation for which PRBC transfusion and ionotropes(dopamine \& noradrenaline) were started. Hemodialysis was done 12 hours after delivery as the patient was oliguric and developed acidosis. BP again went up to $180 / 120 \mathrm{mmHg}$ on $2^{\text {nd }}$ postoperative day and nitroglycerine infusion was started. She had an episode of PPH on the $2^{\text {nd }}$ day which was managed with oxytocics, PRBC \& FFP transfusions. Urine output and acidosis were improving and potassium level was corrected but creatinine level increased. She was extubated on $2^{\text {nd }}$ postoperative day. Labetalol, inapure and amlodipine were started. Nebulisation and diuretics were continued.

Patient was improving clinically with gradual control of $\mathrm{BP}$ and maintaining $\mathrm{O}_{2}$ saturation. Liver enzymes levels were also declining. Gradually from $4^{\text {th }}$ postoperative day creatinine levels started falling. Urinary albumin was trace. Baby was discharged from NICU and she was discharged on $10^{\text {th }}$ postoperative day with amlodipine, furosemide and ursodeoxycholic acid and followed up by cardiologist, gastroenterologist and nephrologist in OPD.

\section{Discussion}

Bello $\mathrm{N}$ et al ${ }^{3}$ found 4 times increased risk of PPCM in preeclamptic patients. Also, hypertension might increase the severity of PPCM ${ }^{6}$. Early symptoms of PPCM such as fatigue, dyspnea, and edema which are seen in later half of pregnancy may be confused with normal pregnancy manifestations. Later symptoms are identical to those of congestive heart failure ${ }^{2}$. Additionally, preeclampsia may manifest with symptoms of respiratory distress due to pulmonary edema ${ }^{7}$. Our case also presented with respiratory distress with uncontrolled BP.

Treatment of PPCM includes stabilising hemodynamics, relief of symptoms, and treatment of precipitating factors ${ }^{2}$. Judicious use of diuretics to relieve pulmonary edema, afterload reduction to decrease the work load of the heart, and control of hypertension ${ }^{2}$ are necessary. In our case we used nitroglycerine infusion mostly to control hypertension and to reduce afterload. Labetalol, which was administered to this patient, is commonly used to treat hypertension; however, it may worsen cardiac function and contribute to pulmonary edema, and thus was used cautiously. Loop diuretic was also used. Afterload reduction has the risk of FHR deterioration. Strict fetal monitoring is thus recommended. Clinical recovery is considered with symptomatic relief and when all circulatory support drugs have been tapered. Recovery usually takes up to 2 months. However, it can take 6-12 months for complete recovery ${ }^{8}$.

In preeclampsia $70 \%$ patients develop the pathognomic renal lesion i.e. glomeruloendotheliosis. Also, there is an overall decrease in GFR and effective renal plasma flow in preeclampsia by $32 \%$ and $24 \%$ respectively as compared with normal pregnancy. Additionally, preeclampsia can also predispose to AKI through secondary effects of relative intravascular volume depletion, vasoconstriction, and activation of the inflammatory and coagulation cascades. In preeclampsia related ARF, the primary pathologic process is acute tubular necrosis, with the most severe cases developing renal cortical necrosis'.

In the case of preeclampsia related AKI, delivery is indicated, as termination of pregnancy is the only effective treatment of preeclampsia. If the conceptus is mature, it should be delivered as soon as the mother's condition has been stabilized. Prognosis of the fetus is usually worse than that of the mother. Mode of delivery depends on various clinical factors. AKI management is primarily supportive and includes maintenance of 
intravascular volume and electrolyte balance and renal replacement therapy as needed. In our case, patient had hyperkalemia which was managed with appropriate medications. But after operation patient developed oliguria and acidosis for which hemodialysis was required.

Our patient was also a known case of hypothyroidism, controlled on medication. Hypothyroidism also predisposes to heart failure which causes a hypodynamic cardiovascular state associated with reduced left ventricular systolic and diastolic function ${ }^{10}$.

\section{Conclusion}

A high index of suspicion is required to diagnose PPCM, specially in cases of preeclampsia as it is difficult to diagnose whether the patient with dyspnea or edema has heart failure or not. Early diagnosis, intervention and treatment may prevent or lessen symptoms of PPCM and improve maternal and fetal outcomes. A cardiac evaluation is very much necessary even in slightest suspicion in these cases.

Acknowledgement: We thank Dr. Alakananda \& Apollo Hospitals for their valuable help.

\section{Conflict of interest: None. Disclaimer: Nil.}

\section{References}

1.Martin S, Short D, Wong CM, McLellan D. A Change of Heart: Case Series of Peripartum Cardiomyopathy. Case Reports in Obstetrics and Gynecology. 2013; 2013 (Article ID 563158): 4 pages.

2.Selle T, Renger I, Labidi S, Bultmann I, Hilfiker-Kleiner D. Reviewing peripartum cardiomyopathy: current state of knowledge. Future Cardiol. 2009; 5(2):175-89.

3.Bello N, Rendon ISH, Arany Z. The relationship between pre-eclampsia and peripartum cardiomyopathy: a systematic review and meta-analysis. J AmColl Cardiol. 2013; 62(18):1715- 23

4.Elkayam U. Clinical characteristics of peripartum cardiomyopathy in the United States: diagnosis, prognosis, and management. J AmColl Cardiol. 2011; 58(7): 659-70.

5.Drakeley AJ, Le Roux PA, Anthony J, Penny J. Acute renal failure complicating severe preeclampsia requiring admission to an obstetric intensive care unit. Am J Obstet Gynecol. 2002; 186(2): 253-6.

6.Kai H, Kudo H, Takayama N, Yasuoka S, Kajimoto H, Imaizumi T. Large blood pressure variability and hypertensive cardiac remodeling: Role of cardiac inflammation. Circ J. 2009; 73(12): 2198 - 203.

7.Sibai BM, Stella CL. Diagnosis and management of atypical preeclampsia - eclampsia. Am J Obstet Gynecol. 2009; 200(5): 481.e1-7.

8.Bhakta P, Biswas BK, Banerjee B. Peripartum cardiomyopathy: review of the literature. Yonsei Med J. 2007; 48(5): 731-7.

9.Iu YM, Bao HD, Jiang ZZ, Huang YJ, Wang NS. Pregnancy-related Acute Kidney Injury and a Review of the Literature in China. Intern Med. 2015; 54(14):1695-703.

10.Fraczek MM, Lacka K. Thyroid hormone and the cardiovascular system. Pol Merkur Lekarski. 2014; 37(219): $170-4$.

\footnotetext{
Tonmoy Das ${ }^{1}$, Alaka Goswami ${ }^{2}$, Himleena Gautam ${ }^{3}$, Maileng Tham ${ }^{4}$, Anupama Hajong ${ }^{5}$, Nahid Farzin ${ }^{6}$, Nilanjana Das $^{7}$

${ }^{1}$ Consultant, Department of Nephrology; ${ }^{2}$ Consultant, Department of Obstetrics and Gynaecology, $3,4,5,6,7$ Resident, Department of Obstetrics and Gynaecology, Apollo Hospitals, Guwahati, Assam.
} 